\title{
Growth, Structure and Physical Properties of Tetraaqua Bismaleatocobalt (II) Crystals
}

\author{
V Mahalakshmi, A Lincy, J Thomas and KV Saban \\ Smart Materials Analytic Research and Technology (SMART), St. Berchmans College, Changanassery-686101, \\ Kerala, India.
}

\begin{abstract}
Tetraaqua bismaleatocobalt(II) crystals are grown by the controlled ionic diffusion in hydrosilica gel. The functional groups present in the crystal are identified using FTIR spectrum. The compound crystallizes in the triclinic system with space group P-1. The thermogravimetric studies revealed a three stage decomposition scheme. The polarization mechanism of the compound is explored using the dielectric measurements. The optical band gap of the material is found to be $2.4 \mathrm{eV}$ from diffuse reflectance spectroscopy $(D R S)$. The narrow magnetic hysteresis loop and structural considerations indicate the weak ferromagnetic behaviour of the material.
\end{abstract}

Keywords - Crystal structure, Diffuse reflectance spectroscopy (DRS), Infrared spectroscopy, Thermogravimetric analysis (TGA), $X$-ray diffraction

\section{INTRODUCTION}

Many crystals of metal coordination complexes like oxalates [1], tartrates [2], malates [3-4], and malonates [5-8] exhibit properties like ferroelectricity, piezoelectricity, photoconductivity and photoluminescence and have become technologically important. The coordination complexes of maleic acid with various transition and rare earth metals [9-10] have displayed interesting optical, magnetic and electrical properties, mainly due to their structural versatility. Details on the structure of certain precipitated metal maleates are found in literature [11 -13]. Although a report on the isomorphous series of compounds bearing the general formula $\mathrm{M}\left(\mathrm{HC}_{4} \mathrm{H}_{2} \mathrm{O}_{4}\right)_{2} \cdot 4 \mathrm{H}_{2} \mathrm{O}$, where $\mathrm{M}=\mathrm{Zn}, \mathrm{Ni}$ and $\mathrm{Co}[14]$ is available, the detailed structure and properties of cobalt maleate is not explored till date. Conventional solution growth techniques seem unsuitable in yielding device grade crystals of metal maleates. Recently, we have resorted to the method of controlled diffusion of ionic species in hydrosilica gel medium and obtained strain free, optical quality crystals of barium maleate [15]. Here, we report the growth of prismatic crystals of cobalt maleate by the above method. Its structure as well as thermal, optical, electrical and magnetic behavior is elucidated.

\section{EXPERIMENTAL}

Gel matrices were prepared in straight glass tubes by titrating sodium meta silicate solution against aqueous maleic acid till a desired $\mathrm{pH}$ was obtained [16]. Ensuring proper gelation, aqueous cobaltous chloride solution was gently poured over, and the tubes were hermitically sealed and kept undisturbed at room temperature. Many batches of experiments corresponding to different densities of the gel $(1.02 \mathrm{gm} / \mathrm{cc}$ $1.07 \mathrm{gm} / \mathrm{cc})$ and $\mathrm{pH}$ values of the medium $(4-7$, in steps of 0.1$)$ were conducted. The strength of the inner and supernatant reactants was altered from $0.25 \mathrm{M}$ to $2 \mathrm{M}$ in different trials.

The FTIR spectrum was recorded using a Thermo Nicolet Avtar 370 model spectrophotometer, in the wave number range $400 \mathrm{~cm}^{-1}-4000 \mathrm{~cm}^{-1}$ with a resolution of $4 \mathrm{~cm}^{-1}$, by KBr pellet method. A fine crystal of size $0.30 \times 0.20 \times 0.20 \mathrm{~mm}^{3}$, formed at gel solution interface, was chosen for single crystal X-ray diffraction (XRD) analysis. The Bruker AXS Kappa Apex2 CCD Diffractometer with graphite monochromated Mo-Ka radiation was employed for the diffraction studies. The data collection, cell refinement and data reduction were done using the software APEX2/SAINT [17]. The crystal structure was solved using SIR92 [18] and was refined using SHELXL-97 [19 -20]. The Full-matrix least squares refinement based on 1105 reflections and 113 parameters, converged the residuals to $R_{l}=0.0258, w R_{2}=0.0728$. The thermal response of the material was traced using Perkin Elmer made Pyris Diamond TG - DTA analyzer by heating the sample in nitrogen atmosphere from room temperature to $820{ }^{\circ} \mathrm{C}$ at a rate of $20{ }^{\circ} \mathrm{C} /$ minute. Dielectric measurements on silver electroded pellets were carried out using Hioki $3532-50 \mathrm{Hi}$ tester. The pellets used were of diameter $1.3 \mathrm{~cm}$ and thickness $1 \mathrm{~mm}$. Measurements were carried out from $303 \mathrm{~K}$ to $373 \mathrm{~K}$ in the frequency range $50 \mathrm{~Hz}-2$ MHz. The Diffused Reflectance from the sample was collected using Cary 5E UV-Vis-NIR spectrophotometer in the range $200 \mathrm{~nm}-2100 \mathrm{~nm}$. The isothermal magnetization measurements were carried on powdered samples using EC\&G PARC VSM 155 Vibrating Sample Magnetometer. 


\subsection{Crystal formation}

\section{RESULTS AND DISCUSSION}

Prismatic and well faceted crystals of the title compound that began to grow in the gel-solution interface in about 4 to 5 months attained their maximum size in another couple of months. They were transparent and deep purple in colour. Better crystals were formed in a gel of density $1.06 \mathrm{gm} / \mathrm{cc}$ at $\mathrm{pH} 6$ corresponding to $0.75 \mathrm{M}$ and $2 \mathrm{M}$ concentrations respectively of inner and outer reactants. Crystals of dimensions upto $10 \times 7 \times 6 \mathrm{~mm}^{3}$ were yielded (Fig.1).

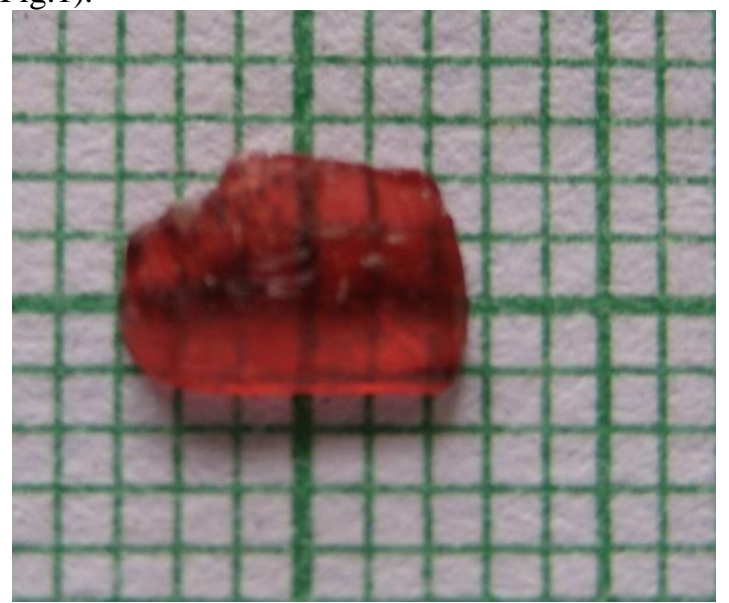

Figure 1. Photograph of the grown crystal.

\subsection{FTIR spectral analysis}

The recorded FTIR spectrum (Fig. 2) bears the signatures of all the functional groups present in the compound. It is interpreted in the light of the established data for similar compounds [21 - 22]. The bands assigned to various vibrations are shown in Table1.

The broad envelope in the high energy region at $3386.51 \mathrm{~cm}^{-1}$ is due to symmetric stretching mode of water molecule, while the weak band at $3056.13 \mathrm{~cm}^{-1}$ represents its stretching mode. Asymmetric and symmetric stretching of the carboxylate group occurs at wavenumbers $1556.41 \mathrm{~cm}^{-1}$ and $1396.53 \mathrm{~cm}^{-1}$ respectively and the strong band observed at $1681.93 \mathrm{~cm}^{-1}$ is due to the asymmetric stretching of $\mathrm{C}=\mathrm{O}$. The bands at $1484.21 \mathrm{~cm}^{-1}$ and $1364.20 \mathrm{~cm}^{-1}$ corresponds to $\mathrm{C}=\mathrm{C}$ stretching. The absorption peaks at $1225.29 \mathrm{~cm}^{-1}$ and $942.93 \mathrm{~cm}^{-1}$ are respectively due to the bending of the $\mathrm{C}-\mathrm{O}-\mathrm{H}$ group, in and out of plane. The asymmetric and symmetric stretching modes of C-C bond occurs at wavenumbers $1120.73 \mathrm{~cm}^{-1}$ and $898.48 \mathrm{~cm}^{-1}$ in order. The $\mathrm{C}-\mathrm{H}$ group bends out of plane at $865.98 \mathrm{~cm}^{-1}$. The bands at $804.33 \mathrm{~cm}^{-1}$ and $512.21 \mathrm{~cm}^{-1}$ are ascribed to the deformation of the $\mathrm{O}-\mathrm{H}$ group. The absorption at $748 \mathrm{~cm}^{-1}$ is due to the vibrations of the $-\mathrm{CH}$ group. The metal oxygen stretching occurs at $670.54 \mathrm{~cm}^{-1}$.

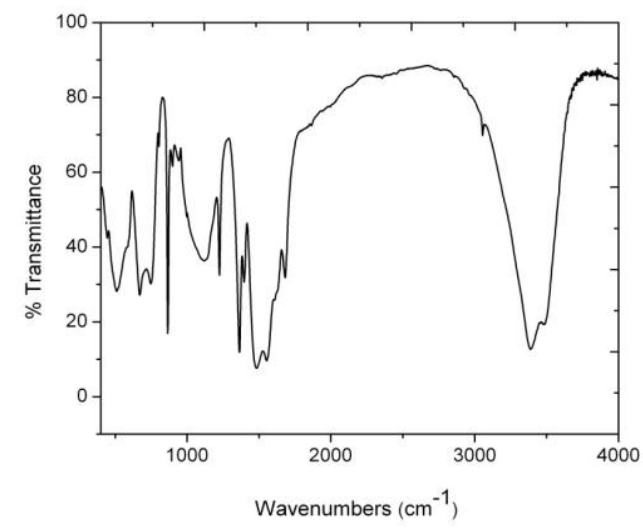

Figure 2. FTIR spectrum of the crystal. 
Table 1. Spectral assignments of IR peaks.

\begin{tabular}{ll}
\hline Wave Number $\left(\mathrm{cm}^{-1}\right)$ & Assignment \\
\hline 3386.51 & $v_{\mathrm{as}} \mathrm{H}-\mathrm{O}-\mathrm{H}$ \\
3056.13 & $\mathrm{v}_{\mathrm{s}} \mathrm{H}-\mathrm{O}-\mathrm{H}$ \\
1681.93 & $\mathrm{v}_{\mathrm{as}} \mathrm{C}=\mathrm{O}$ \\
1556.41 & $\mathrm{vas}_{\mathrm{as}} \mathrm{O}-\mathrm{C}=\mathrm{O}$ \\
1484.21 & $\mathrm{vas}_{\mathrm{as}} \mathrm{C}=\mathrm{C}$ \\
1396.53 & $\mathrm{v}_{\mathrm{s}} \mathrm{O}-\mathrm{C}=\mathrm{O}$ \\
1364.20 & $\mathrm{v}_{\mathrm{s}} \mathrm{C}=\mathrm{C}$ \\
1225.29 & $\delta \mathrm{C}-\mathrm{O}-\mathrm{H}$ in plane \\
1120.73 & $\mathrm{v}_{\mathrm{as}} \mathrm{C}-\mathrm{C}$ \\
942.93 & $\delta \mathrm{C}-\mathrm{O}-\mathrm{H}$ out of plane \\
898.48 & $\mathrm{v}_{\mathrm{s}} \mathrm{C}-\mathrm{C}$ \\
865.98 & $\delta \mathrm{C}-\mathrm{H}$ out of plane \\
804.33 & $\rho_{\mathrm{w}} \mathrm{H}_{2} \mathrm{O}$ \\
748.00 & $\pi \mathrm{C}-\mathrm{H}$ \\
670.54 & $v \mathrm{M}-\mathrm{O}$ \\
512.21 & $\rho_{\mathrm{t}} \mathrm{H}_{2} \mathrm{O}$ \\
\hline
\end{tabular}

\subsection{Crystal structure analysis}

Single crystal $\mathrm{X}$-ray diffraction studies reveals that the crystallized complex is tetraaqua bismaleatocobalt (II) $\left(\mathrm{Co}\left(\mathrm{C}_{4} \mathrm{H}_{3} \mathrm{O}_{4}\right)_{2} .4 \mathrm{H}_{2} \mathrm{O}\right)$. It crystallizes in the triclinic system with space group $P-1$. The unit cell dimensions are $\quad a=5.213(5) \AA, b=7.320(5) \AA, c=9.216(5) \AA, \alpha=109.170(5)^{\circ}, \beta=104.372(5)^{\circ}, \gamma$ $=93.203(5)^{\circ}$. The crystal structure and refinement data are shown in Table 2. The ORTEP [23 - 25] of the molecule, drawn with thermal ellipsoids at 50\% probability (Fig. 3), illustrates the structure of the molecule. It is seen that four water molecules are coordinated to the central cobalt ion forming a square base in a plane. Two maleate ligands are monodendately coordinated to the same cobaltous ion resulting in square bipyramidal geometry. The polymeric structure (Fig. 4) clearly shows the packing of the molecule in the triclinic lattice. Tables 3 and 4 list the selected bond lengths and bond angles in order.

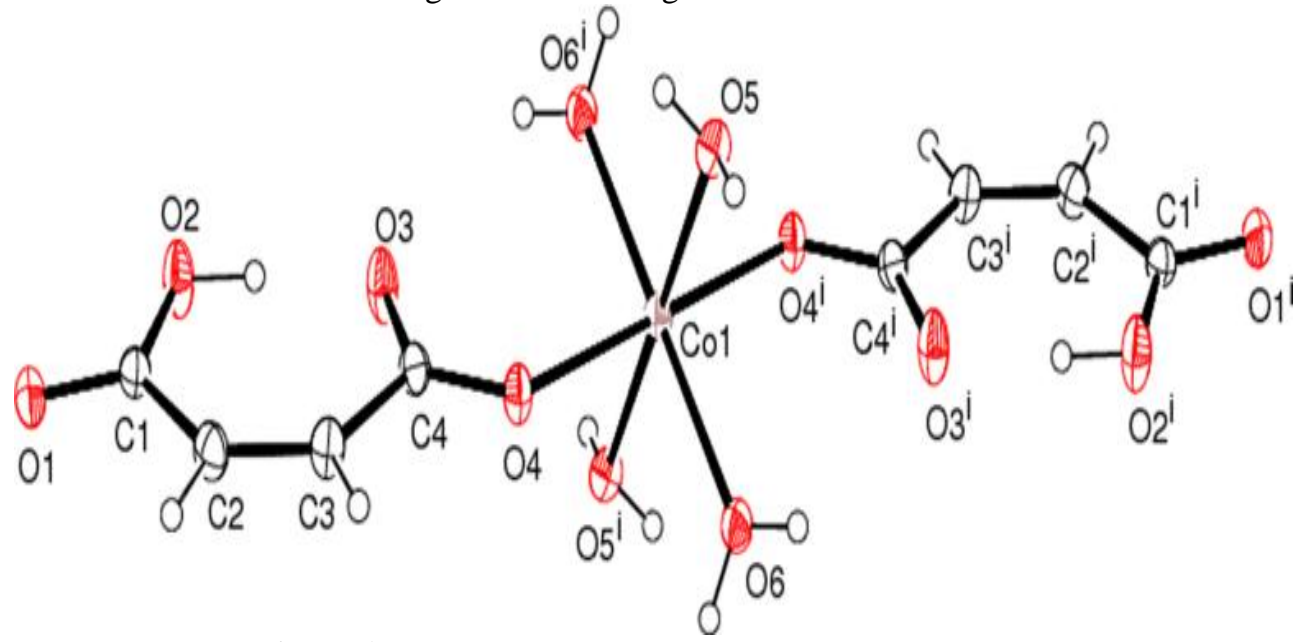

Figure 3. ORTEP of the molecule with $50 \%$ probability.

Table 2. Crystal data and structure refinement.

\begin{tabular}{ll}
\hline Empirical formula & $\mathrm{C}_{8} \mathrm{H}_{14} \mathrm{Co}_{12}$ \\
Formula weight & 361.12 \\
Temperature & $293(2) \mathrm{K}$ \\
Wavelength & $0.71073 \AA$ \\
Crystal system, space group & Triclinic, $P-1$ \\
Unit cell dimensions & $a=5.213(5) \AA, \alpha=$ \\
& $109.170(5)^{\circ}$ \\
& $b=7.320(5) \AA, \beta=$ \\
Volume & $104.372(5)^{\circ}{ }^{\circ}$ \\
Z, Calculated density & $c=9.216(5) \AA, \gamma=$ \\
Absorption coefficient & $93.203(5)^{\circ}$ \\
F(000) & $318.1(4) \AA^{3}$ \\
Crystal size & $1,1.885 \mathrm{Mg}^{\circ} \mathrm{m}^{3}$ \\
$\theta$ range for data collection & $1.415 \mathrm{~mm}^{-1}$ \\
\hline
\end{tabular}




\begin{tabular}{ll}
\hline Limiting indices & 185 \\
Reflections collected / unique & $0.30 \mathrm{~mm} \times 0.20 \mathrm{~mm} \times 0.20$ \\
Completeness to $\theta=24.99^{\circ}$ & $\mathrm{mm}$ \\
Absorption correction & $2.44^{\circ}$ to $24.99^{\circ}$ \\
Max. and min. transmission & $-6 \leq h \leq 6,-8 \leq k \leq 8,-10 \leq$ \\
Refinement method & $l \leq 10$ \\
Data / restraints / parameters & $5456 / 1105[R(\mathrm{int})=$ \\
Goodness-of-fit on $F^{2}$ & $0.0323]$ \\
Final $R$ indices $[\mathrm{I}>2 \sigma(\mathrm{I})]$ & $98.7 \%$ \\
$R$ indices (all data) & Semi-empirical from \\
Largest diff. peak and hole & equivalents \\
& 0.7781 and 0.6652 \\
& Full-matrix least-squares on \\
& $F^{2}$ \\
& $1105 / 4 / 113$ \\
& 1.171 \\
& $R_{1}=0.0258, w R_{2}=0.0728$ \\
& $R_{1}=0.0261, w R_{2}=0.0732$ \\
& 0.633 and $-0.356 \mathrm{e} \AA^{-3}$ \\
\hline
\end{tabular}

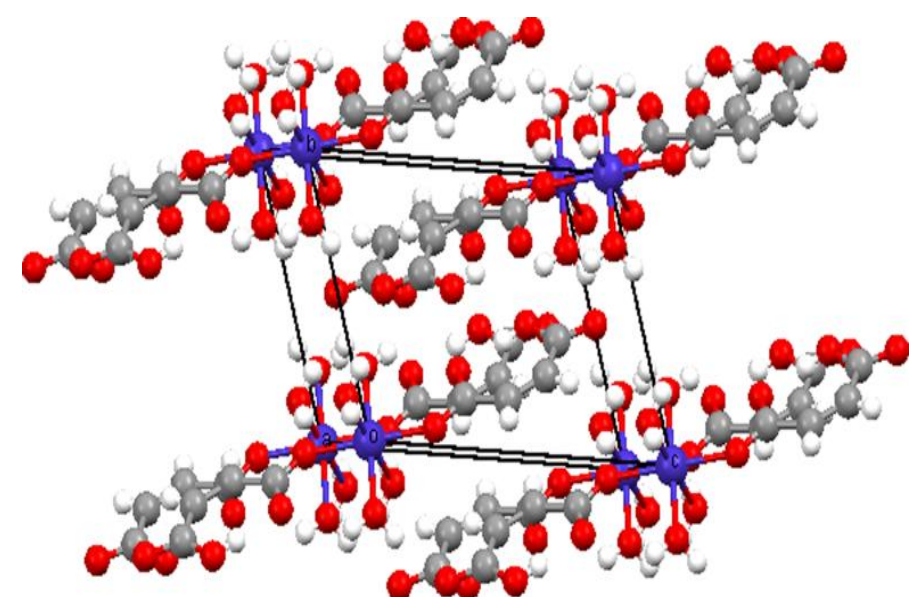

Figure 4. Polymeric structure of cobalt maleate tetrahydrate.

Table 3. Bond lengths in tetraaqua bismaleatocobalt(II).

\begin{tabular}{ll}
\hline Bond & Length $(\AA)$ \\
\hline $\mathrm{C}(1)-\mathrm{O}(1)$ & $1.224(2)$ \\
$\mathrm{C}(1)-\mathrm{O}(2)$ & $1.287(3)$ \\
$\mathrm{C}(1)-\mathrm{C}(2)$ & $1.485(3)$ \\
$\mathrm{C}(2)-\mathrm{C}(3)$ & $1.334(3)$ \\
$\mathrm{C}(2)-\mathrm{H}(2)$ & 0.9300 \\
$\mathrm{C}(3)-\mathrm{C}(4)$ & $1.488(3)$ \\
$\mathrm{C}(3)-\mathrm{H}(3)$ & 0.9300 \\
$\mathrm{C}(4)-\mathrm{O}(4)$ & $1.249(2)$ \\
$\mathrm{C}(4)-\mathrm{O}(3)$ & $1.262(3)$ \\
$\mathrm{O}(2)-\mathrm{H}(2 \mathrm{~A})$ & 0.8200 \\
$\mathrm{O}(4)-\mathrm{Co}(1)$ & $2.1191(16)$ \\
$\mathrm{O}(5)-\mathrm{Co}(1)$ & $2.1258(17)$ \\
$\mathrm{O}(5)-\mathrm{H}(5 \mathrm{~A})$ & $0.836(10)$ \\
$\mathrm{O}(5)-\mathrm{H}(5 \mathrm{~B})$ & $0.830(10)$ \\
$\mathrm{O}(6)-\mathrm{Co}(1)$ & $2.0410(17)$ \\
$\mathrm{O}(6)-\mathrm{H}(6 \mathrm{~B})$ & $0.842(10)$ \\
$\mathrm{O}(6)-\mathrm{H}(6 \mathrm{~A})$ & $0.839(10)$ \\
$\mathrm{Co}(1)-\mathrm{O}(6) \# 1$ & $2.0410(17)$ \\
$\mathrm{Co}(1)-\mathrm{O}(4) \# 1$ & $2.1191(16)$ \\
$\mathrm{Co}(1)-\mathrm{O}(5) \# 1$ & $2.1258(18)$ \\
\hline
\end{tabular}


Table 4. Bond angles of tetraaqua bismaleatocobalt(II).

\begin{tabular}{|c|c|c|c|}
\hline Bond & Angle $\left(^{\circ}\right)$ & Bond & Angle $\left(^{\circ}\right)$ \\
\hline $\mathrm{O}(1)-\mathrm{C}(1)-\mathrm{O}(2)$ & $121.36(18)$ & $\mathrm{Co}(1)-\mathrm{O}(6)-\mathrm{H}(6 \mathrm{~A})$ & $121(2)$ \\
\hline $\mathrm{O}(1)-\mathrm{C}(1)-\mathrm{C}(2)$ & $118.47(18)$ & $\mathrm{H}(6 \mathrm{~B})-\mathrm{O}(6)-\mathrm{H}(6 \mathrm{~A})$ & $115(3)$ \\
\hline $\mathrm{O}(2)-\mathrm{C}(1)-\mathrm{C}(2)$ & $120.15(17)$ & $\mathrm{O}(6)-\mathrm{Co}(1)-\mathrm{O}(6) \# 1$ & 180.0 \\
\hline$C(3)-C(2)-C(1)$ & $130.55(18)$ & $\mathrm{O}(6)-\mathrm{Co}(1)-\mathrm{O}(4) \# 1$ & $96.35(6)$ \\
\hline $\mathrm{C}(3)-\mathrm{C}(2)-\mathrm{H}(2)$ & 114.7 & $\mathrm{O}(6) \# 1-\mathrm{Co}(1)-\mathrm{O}(4) \# 1$ & $83.65(6)$ \\
\hline $\mathrm{C}(1)-\mathrm{C}(2)-\mathrm{H}(2)$ & 114.7 & $\mathrm{O}(6)-\mathrm{Co}(1)-\mathrm{O}(4)$ & $83.65(6)$ \\
\hline $\mathrm{C}(2)-\mathrm{C}(3)-\mathrm{C}(4)$ & $130.18(18)$ & $\mathrm{O}(6) \# 1-\mathrm{Co}(1)-\mathrm{O}(4)$ & $96.35(6)$ \\
\hline $\mathrm{C}(2)-\mathrm{C}(3)-\mathrm{H}(3)$ & 114.9 & $\mathrm{O}(4) \# 1-\mathrm{Co}(1)-\mathrm{O}(4)$ & $180.00(8)$ \\
\hline $\mathrm{C}(4)-\mathrm{C}(3)-\mathrm{H}(3)$ & 114.9 & $\mathrm{O}(6)-\mathrm{Co}(1)-\mathrm{O}(5) \# 1$ & $88.66(8)$ \\
\hline $\mathrm{O}(4)-\mathrm{C}(4)-\mathrm{O}(3)$ & $122.96(17)$ & $\mathrm{O}(6) \# 1-\mathrm{Co}(1)-\mathrm{O}(5) \# 1$ & $91.34(8)$ \\
\hline $\mathrm{O}(4)-\mathrm{C}(4)-\mathrm{C}(3)$ & $116.50(17)$ & $\mathrm{O}(4) \# 1-\mathrm{Co}(1)-\mathrm{O}(5) \# 1$ & $88.28(7)$ \\
\hline $\mathrm{O}(3)-\mathrm{C}(4)-\mathrm{C}(3)$ & $120.54(17)$ & $\mathrm{O}(4)-\mathrm{Co}(1)-\mathrm{O}(5) \# 1$ & $91.72(7)$ \\
\hline $\mathrm{C}(1)-\mathrm{O}(2)-\mathrm{H}(2 \mathrm{~A})$ & 109.5 & $\mathrm{O}(6)-\mathrm{Co}(1)-\mathrm{O}(5)$ & $91.34(8)$ \\
\hline $\mathrm{C}(4)-\mathrm{O}(4)-\mathrm{Co}(1)$ & $127.65(12)$ & $\mathrm{O}(6) \# 1-\mathrm{Co}(1)-\mathrm{O}(5)$ & $88.66(8)$ \\
\hline $\mathrm{Co}(1)-\mathrm{O}(5)-\mathrm{H}(5 \mathrm{~A})$ & $110.3(18)$ & $\mathrm{O}(4) \# 1-\mathrm{Co}(1)-\mathrm{O}(5)$ & $91.72(7)$ \\
\hline $\mathrm{Co}(1)-\mathrm{O}(5)-\mathrm{H}(5 \mathrm{~B})$ & $116.8(16)$ & $\mathrm{O}(4)-\mathrm{Co}(1)-\mathrm{O}(5)$ & $88.28(7)$ \\
\hline $\mathrm{H}(5 \mathrm{~A})-\mathrm{O}(5)-\mathrm{H}(5 \mathrm{~B})$ & $102(2)$ & $\mathrm{O}(5) \# 1-\mathrm{Co}(1)-\mathrm{O}(5)$ & 180.0 \\
\hline
\end{tabular}

\subsection{Thermal Studies}

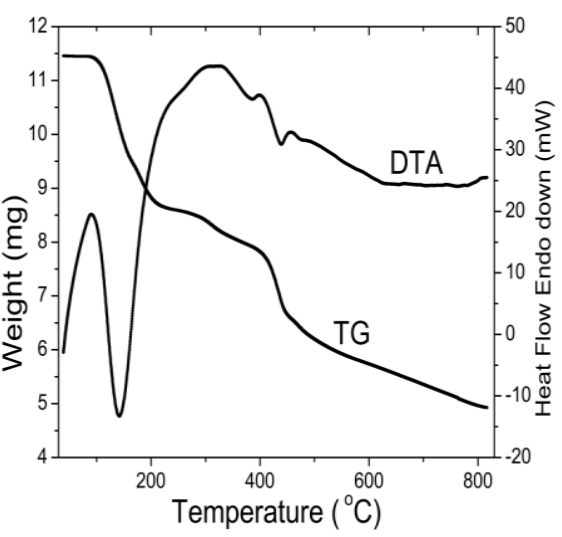

Figure 5. TG - DTA curves of cobalt maleate tetrahydrate.

The thermal stability and decomposition pattern of the grown crystals were evaluated from TG-DTA curves (Fig. 5). The crystal is found to be thermally stable up to $98{ }^{\circ} \mathrm{C}$. It becomes anhydrous in the temperature range $98^{\circ} \mathrm{C}-184^{\circ} \mathrm{C}$. The sharp endothermic peak in the DTA curve at $143{ }^{\circ} \mathrm{C}$ corresponds to this dehydration. Upon heating the sample to $424^{\circ} \mathrm{C}$, the anhydrous cobalt maleate gets transformed to cobalt oxalate, eliminating acetylene and hydrogen molecules. The broad exotherm in DTA at $320{ }^{\circ} \mathrm{C}$ confirms the decomposition. During the next stage of decomposition $\left(424{ }^{\circ} \mathrm{C}-635^{\circ} \mathrm{C}\right)$, two molecules of carbon monoxide are liberated leaving behind cobalt carbonate. The small exothermic peak around $460{ }^{\circ} \mathrm{C}$ in the DTA corresponds to this transformation. The mass loss observed in each stage concurs with the calculated values (Table 5). The TG curve shows gradual weight loss upon further heating indicative of the formation of an ultimate stable product at a temperature above $820^{\circ} \mathrm{C}$.

The stoichiometry of the title compound is evident from the thermal studies also and hence the chemical reaction leading to the formation of the title compound is:

$\mathrm{CoCl}_{2}+2 \mathrm{C}_{4} \mathrm{H}_{4} \mathrm{O}_{4}+4 \mathrm{H}_{2} \mathrm{O} \rightarrow \mathrm{Co}\left(\mathrm{C}_{4} \mathrm{H}_{3} \mathrm{O}_{4}\right)_{2} \cdot 4 \mathrm{H}_{2} \mathrm{O}+2 \mathrm{HCl}$ 
Table 5. The thermal decomposition process of $\mathrm{Co}\left(\mathrm{C}_{4} \mathrm{H}_{3} \mathrm{O}_{4}\right)_{2} \cdot 4 \mathrm{H}_{2} \mathrm{O}$.

\begin{tabular}{cccccc}
\hline Stage & $\begin{array}{l}\text { Decomposition } \\
\text { temperature }\left({ }^{\circ} \mathbf{C}\right)\end{array}$ & $\begin{array}{l}\text { Product after } \\
\text { decomposition }\end{array}$ & $\begin{array}{l}\text { Molecules } \\
\text { evolved }\end{array}$ & $\begin{array}{l}\text { Observed mass } \\
\text { loss (\%) }\end{array}$ & $\begin{array}{l}\text { Calculated mass } \\
\text { loss }(\%)\end{array}$ \\
\hline 1 & $98-184$ & $\mathrm{Co}\left(\mathrm{C}_{4} \mathrm{H}_{3} \mathrm{O}_{4}\right)_{2}$ & $4 \mathrm{H}_{2} \mathrm{O}$ & 19.975 & 19.955 \\
2 & $184-424$ & $\mathrm{Co}\left(\mathrm{C}_{2} \mathrm{O}_{4}\right)_{2}$ & $2 \mathrm{C}_{2} \mathrm{H}_{2}+\mathrm{H}_{2}$ & 14.979 & 14.977 \\
3 & $424-635$ & $\mathrm{Co}\left(\mathrm{CO}_{3}\right)_{2}$ & $2 \mathrm{CO}$ & 15.513 & 15.512 \\
\hline
\end{tabular}

\subsection{Dielectric Studies}

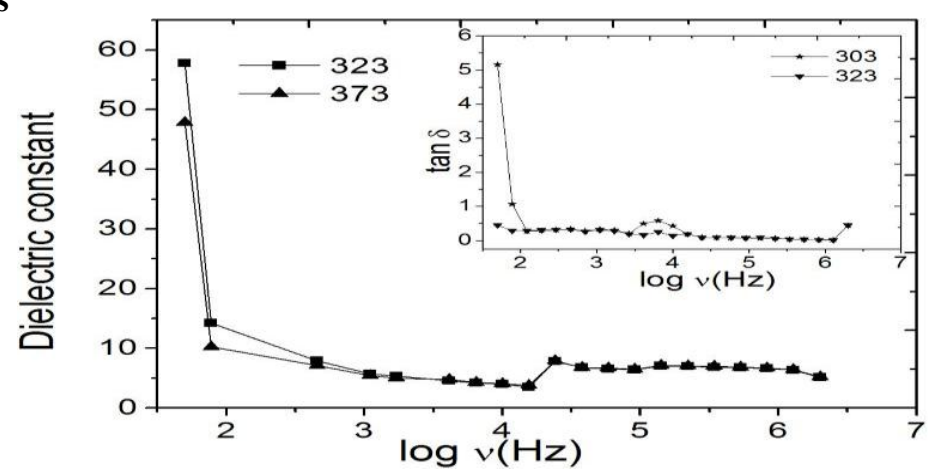

Figure 6. Frequency response of dielectric constant and dielectric loss.

The values of dielectric constant and loss tangent are found to be decreasing with increasing frequency (Fig. 6), indicating that beyond a certain frequency, the polarization could not follow the alternating applied electric field. The relatively higher value of dielectric constant at lower frequencies is due to the interfacial polarization [26-27]. The space charge polarization mechanism gives rise to higher dielectric loss at low frequencies. The characteristic low dielectric loss at higher frequencies is indicative of the optical quality of the crystals. The small peak in loss tangent (inset of Fig. 6) immediately before $\log v=4(v=6430 \mathrm{~Hz})$ is attributed to the position exchange of the metallic ion between its two equally probable potential energy sites. When the frequency of the applied field matches the natural frequency of position change, maximum electrical energy is transferred to the jumping ions resulting in a small resonance peak in the loss tangent [28].

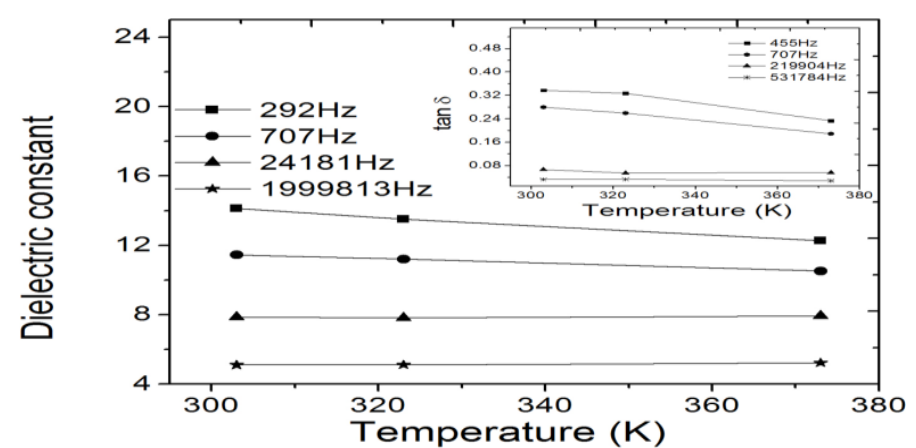

Figure 7. Thermal response of dielectric constant and dielectric loss.

The dielectric constant and dielectric loss are found to be almost temperature independent (Fig. 7), indicative of the good chemical homogeneity [29] and structural stability of the grown crystals.

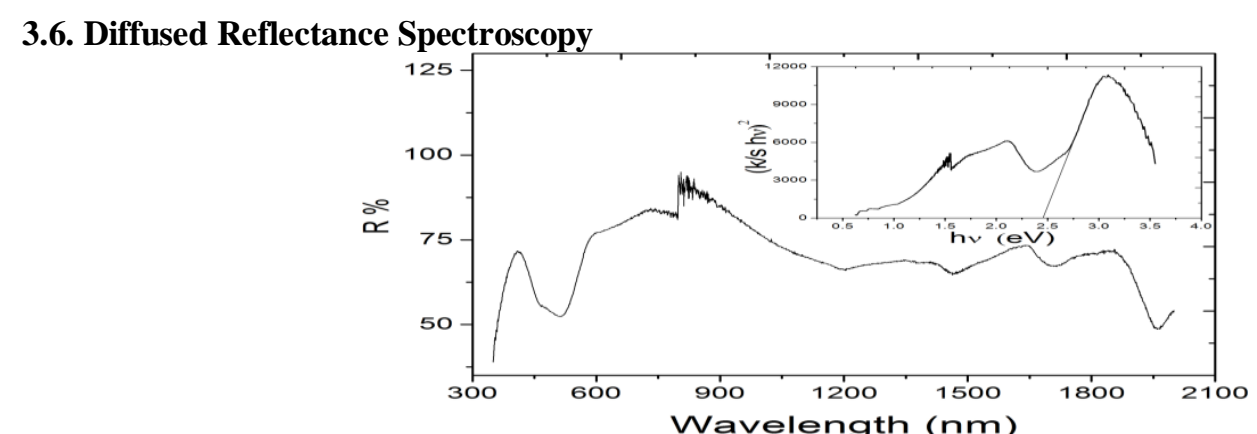

Figure 8. Diffused reflectance spectrum of the compound. 
Fig. 8 presents the diffused reflectance from the sample in the in the UV-Vis-NIR region. Following the Kubelka-Munk method, the optical band gap of the material is determined by plotting $((k / s) h v)^{2}$ versus $h v($ inset of Fig. 8) where $R, k$ and $s$ are the reflectance, absorption and scattering coefficients respectively [30 -31]. The band gap evaluated from the linear fit of the curve on the energy axis is $2.4 \mathrm{eV}$. The low value of the band gap indicates relatively densely packed crystalline nature of the complex [32].

\subsection{Magnetic studies}

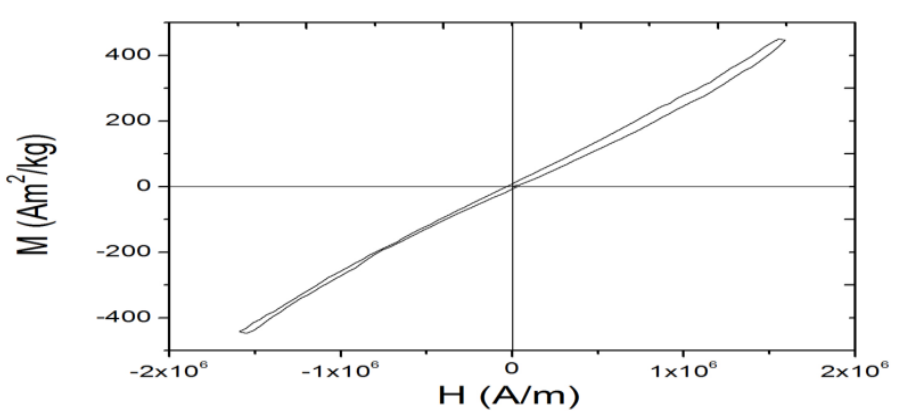

Figure 9. Hysteresis loop of cobalt maleate tetrahydrate.

The VSM measurements yielded a narrow hysteresis loop (Fig. 9) at room temperature. The structure sensitive parameters such as saturation magnetization, remanent magnetization and coercivity are found to be $449.5 \mathrm{Am}^{2} / \mathrm{kg}, 7.762 \mathrm{Am}^{2} / \mathrm{kg}$ and $32006 \mathrm{~A} / \mathrm{m}$ respectively. The structure of the title compound being octahedral, the degeneracy of the $d$ orbitals of $\mathrm{Co}^{2+}$ ions splits into high energy two fold degenerate $e_{g}$ and low energy three fold degenerate $t_{2 g}$. Since the number of unpaired $3 d$ electrons in $\mathrm{Co}^{2+}$ ion is 3 , the complex is in high state. Also, in this material the antiferromagnetic interaction arising due to the overlapping magnetic orbitals does not occur due to the monodentate coordination of the maleate ligands with the metal ion. In brief, the material would exhibit weak ferromagnetism.

\section{CONCLUSION}

Well faceted, purple crystals of cobalt maleate have been grown the by the limited diffusion of cobalt ions into hydrosilica gel impregnated with maleate ions. The FTIR and single crystal XRD studies confirm that the grown crystal is tetraaqua bismaleatocobalt(II) . Also, the single XRD studies proved that the symmetry of the crystal system is triclinic with space group $P$-1. The material is stable up to $98{ }^{\circ} \mathrm{C}$. It exhibits the usual dielectric behavior of metal coordinated carboxylates. The peaking of loss tangent at $6430 \mathrm{~Hz}$ indicates that the metal ion has two equally probable potential energy sites. The optical band gap obtained using the DRS studies is $2.4 \mathrm{eV}$. Magnetic studies in conjunction with structural information show that the material is weakly ferromagnetic.

\section{REFERENCES}

[1] P. V. Dalal and K. B. Saraf, Growth and study of barium oxalate single crystals in agar gel, Bull. Mater. Sci., 29, 2006, 421-425.

[2] S. K. Arora, V. Patel, R. G. Patel, B. Amin and A. Kothari, Electrical characterization of strontium tatrate single crystals, J. Phys. Chem. Solids, 65, 2004, 965-973.

[3] T. Jini, K. V. Saban and G. Varghese, The growth, spectral and thermal properties of the coordination compound crystal- strontium malate, Cryst. Res. Technol., 41, 2006, 250-254.

[4] T. Jini, K. V. Saban, G. Varghese, S. Naveen, M. A. Sridhar and J. S. Prasad, Growth, crystal structure and thermal properties of calcium bis(malate) dihydrate, J. Alloys Compd., 433, 2007, 211-215.

[5] A. Lincy, V. Mahalakshmi, A. J. Tinto, J. Thomas and K. V. Saban, Structural, thermal and dielectric properties of cobaltous malonate single crystals grown in limited diffusion media, Physica B, 405, 2010, 4673-4677.

[6] B. H. Doreswamy, M. Mahendra, M. A. Sridhar, J. S. Prasad, P. A. Varughese, J. George and G. Varghese, A novel threedimensional polymeric structure of crystalline neodymium malonate hydrate, Mater. Lett., 59, 2005, 1206-1213.

[7] M. Varghese, X. Lizymol, C. K. Mahadevan and K. E. Abraham, Thermal and dielectric properties of gel-grown cobalt malonate dihydrate crystals, Phys. Scr., 83(3), 2011, 035801-03.

[8] B. Natarajan, S. Mithira and P. Sambasiva Rao, Single-crystal electron paramagnetic resonance study of the interstitial position of $\mathrm{Mn}(\mathrm{II})$ in dipotassium diaquabis(malonato- $\kappa^{2} \mathrm{O}, \mathrm{O}^{\prime}$ ) zincate(II) dihydrate, Phys. Scr., 83(6), $2011,065704$.

[9] P. S. Mukherjee, S. Konar, E. Zangrando, T. Mallah, J. Ribas and N. R. Chaudhuri, Structural analyses and magnetic properties of $3 \mathrm{D}$ coordination polymeric networks of nickel(II) maleate and manganese(II) adipate with the flexible 1,2-bis(4-pyridyl)ethane ligand, Inorg. Chem., 42, 2003, 2695-2703.

[10] G. Oczko, J. Legendziewicz, M. S. Wickleder and G. Meyer, Crystal structure, magnetism and photophysics of the lanthanide maleates $\mathrm{RE}\left(\mathrm{C}_{4} \mathrm{O}_{4} \mathrm{H}_{3}\right)_{3} .8 \mathrm{H}_{2} \mathrm{O}(\mathrm{RE}=\mathrm{Nd}, \mathrm{Sm})$, J. Alloys Compd., 341, 2002, 255-262.

[11] M. N. G. James and G. J. B. Williams, The crystal and molecular structure of disodiurn maleate monohydrate, Acta Cryst., B30, $1974,1257-1262$.

[12] B. Hsu and E. O. Schlemper, Calcium di(hydrogen maleate) pentahydrate, Acta Cryst., B34, 1978, 930-932.

[13] M. P. Gupta, S. M. Prasad and T. N. P. Gupta, The crystal structure of lithium hydrogen maleate dihydrate, $\mathrm{LiC}_{4} \mathrm{H}_{3} \mathrm{O}_{4} .2 \mathrm{H}_{2} \mathrm{O}$, Acta Cryst., B31, 1975, 37-40. 
[14] A. S. Antsyshkina, M. A. Porai-koshits and M. G. Guseinov, Structure of tetrahydrates of Co, Ni and Zn maleates of composition M $\left(\mathrm{HC}_{4} \mathrm{H}_{2} \mathrm{O}_{4}\right)_{2} .4 \mathrm{H}_{2} \mathrm{O}$, Izv. Akad. Nauk SSSR Ser. Khim., 1, 1974, 237.

[15] V. Mahalakshmi, A. Lincy, J. Thomas and K. V. Saban, Crystal growth and characterization of a new co-ordination complexbarium tetrakis(maleate) dihydrate, J. Phys. Chem. Solids, 73, 2012, 584-588.

[16] H. K. Henisch, Crystals in Gels and Liesegang Rings, Chapter 2 (University Press, Cambridge, 1988).

[17] Bruker, APEX2, SAINT and XPREP (Bruker AXS Inc, Madison, Wisconsin, USA, 2004).

[18] A. Altomare, G. Cascarano, C. Giacovazzo and A. Guagliardi, Completion and refinement of crystal structures with SIR92, J. Appl. Cryst., 26, 1993, 343-350.

[19] G. M. Sheldrick, SHELXL-97 Program for the Refinement of Crystal Structures (University of Göttingen, Germany, 1997).

[20] G. M. Sheldrick, A short history of SHELX, Acta Cryst., A64, 2008, 112-122.

[21] L. J. Bellamy, The IR Spectra of Complex Molecules (Chapman and Hall, London, 1975).

[22] K. Nakamoto, Infrared Spectra of Inorganic and Coordination Compounds, Part 3 (John Wiley and Sons, New York, 1963).

[23] A. L. Spek, PLATON, An integrated tool for the analysis of the results of a single crystal structure determination, Acta Cryst., A46, 1990, C34.

[24] A. L. Spek, PLATON, A Multipurpose Crystallographic Tool (University of Utretcht, The Netherlands, 1998).

[25] L. J. Farrugia, Ortep-3 for windows, J. Appl. Cryst., 30, 1997, 565-568.

[26] B. M. Boaz, R. S. Selvaraj, K. S. Kumar and S. Jerome Das, Growth, microhardness, dielectric and photoconductivity characterization of a highly polarizable NLO material: sodium p-nitrophenolate dihydrate $\left(\mathrm{NO}_{2}-\mathrm{C}_{6} \mathrm{H}_{4}-\mathrm{ONa} \cdot 2 \mathrm{H}_{2} \mathrm{O}\right)$, Indian J. Phys, 83 (12), 2009, 1647-1657.

[27] C. J. Raj, S. Krishnan, S. Dinakaran, J. M. Linet, R. Uthrakumar, R. Robert and S. Jerome Das, Growth, optical, mechanical, dielectric and theoretical studies on potassium pentaborate tetrahydrate $\left(\mathrm{KB}_{5} \mathrm{O}_{8} .4 \mathrm{H}_{2} \mathrm{O}\right)$ single crystal by modified Sankaranarayanan-Ramasamy method, J. Mater. Sci. Technol., 25, 2009, 745-748.

[28] S. Chopra, S. Sharma, T. C. Goel and R. G. Mendiratta, Structural, dielectric and pyroelectric studies of $\mathrm{Pb}_{1-x} \mathrm{Ca}_{x} \mathrm{TiO}_{3}$ thin films, Solid State Commun., 127, 2003, 299-304.

[29] G. Ananda Babu, S. Sreedhar, S. V. Rao and P. Ramasamy, Synthesis, growth, structural, thermal, linear and nonlinear optical properties of a new organic crystal: dimethylammonium picrate, J. Cryst. Growth, 312, 2010, 1957-1962.

[30] P. Kubelka and F. Munk, Ein Beitrag zur Optik der Farbanstriche, Zh. Tekh. Fiz., 12, 1931, 593-620.

[31] P. Kubelka, New contributions to the optics of intensely light-scattering materials, Part 1, J. Opt. Soc. Am., 38, 1948, 448-457.

[32] Y. H. Hsien, C. F. Chang, Y. H. Chen and S. Chen, Photodegradation of aromatic pollutants in water over $\mathrm{TiO}_{2}$ supported on molecular sieves, Appl. Catal. B Environ., 31, 2001, 241-249. 